\title{
Perceived understanding of supply chain integration, communication and teamwork competency in the global manufacturing companies
}

\author{
Yudi Fernando \\ Business Engineering Department, Faculty of Industrial Management, \\ Universiti Malaysia Pahang, Kuantan, Malaysia and \\ Management Department, BINUS Online Learning, Bina Nusantara University, \\ Jakarta Barat, Indonesia, and \\ Puspita Wulansari \\ School of Economics and Business, Telkom University, Bandung, Indonesia
}

\begin{abstract}
Purpose - This study empirically examines a model that describes the direct path from perceived understanding of supply chain integration (PUSCI) to perceived understanding of supply chain responsiveness (PUSCR) to leverage supply chain manager's communication and teamwork competencies. This study also examines whether knowledge and task skill and proficiency mediate the relationship between PUSCI and PUSCR to improve the communication and teamwork competency of a supply chain manager.

Design/methodology/approach - The data were collected using a survey questionnaire that was mailed to the 413 supply chain managers of global manufacturing companies in Indonesia.

Findings - The result from model testing shows that PUSCR significantly and positively affected the communication and teamwork competency of supply chain manager and knowledge, task skill and proficiency as mediating variables improved communication and teamwork competency. The results found that PUSCI was related to supply chain manager's competency.

Practical implications - Supply chain managers are advised to focus on PUSCI and consistently improve effective communication and teamwork competency.

Originality/value - This study will extend the literature by utilizing the competency-based theory to investigate the perceived understanding and communication capabilities of supply chain managers.

Keywords Perceived understanding, Supply chain integration, Supply chain responsiveness, Supply chain manager, Global manufacturing

Paper type Research paper
\end{abstract}

\section{Introduction}

Globalization is inevitably shaping our daily lives, as the interrelationships and interdependencies among and between countries have increased and steadily grown (Kim and McLean, 2015). The globalization of supply chains implies that various infrastructures, climates and cultures now affect the production of many goods and services (Simangunsong

(C) Yudi Fernando and Puspita Wulansari. Published in European Journal of Management and Business Economics. Published by Emerald Publishing Limited. This article is published under the Creative Commons Attribution (CC BY 4.0) licence. Anyone may reproduce, distribute, translate and create derivative works of this article (for both commercial and non-commercial purposes), subject to full attribution to the original publication and authors. The full terms of this licence may be seen at http:// creativecommons.org/licences/by/4.0/legalcode.

The authors convey their appreciation to the Division of Research and Innovation, Universiti Malaysia Pahang for funding this study (UIC181505; RDU1903126; and RDU172207). 
EJMBE 30,2

192 et al., 2016). Global sourcing and cost reduction initiatives drive companies to work with a diverse set of suppliers (Kattman, 2014) and these cause supply chain management (SCM) to be more complex than ever before (Hohenstein et al., 2014). The role of a supply chain manager has become critical in both achieving a company's operational objectives and in successfully implementing its business strategy, especially when competing globally. The supply chain managers need to improve a set of skills consistently. They should not rely much on personal relationship in inter-firm relationships. It will be triggered of various conflicts when the supply chain underperforms (Butt and Ahmad, 2019). Therefore, nowadays to have a competent supply chain manager is a key driver of business success (Prajogo and Sohal, 2013). Thus, the globalization phenomenon has impacted the development of SCM in practice and in research (Shou and Wang, 2017).

To recruit, train and retain a qualified supply chain manager is not an easy task. A company must perform a series of human resource activities, which are selecting, training and retaining competent supply chain managers (Harvey et al., 2013). A successful supply chain manager must possess the necessary talents to execute a comprehensive SCM strategy, tackle the day-to-day operational challenges and interact with other departments and external network partners on a global scale. Unfortunately, even though supply chain is known to be a critical management function of a company in competing globally, the literature on talent management in SCM remains scarce. The limited literature on the development of talented supply chain managers has caused increasing challenges to measure the competence of supply chain professionals. The skills needed are several and include technical skills and soft skills. Technical skills and soft skills are two main competency domains that contribute to the knowledge of a supply chain professional, and these will assist them in making business decisions. A supply chain manager is expected not only to have technical knowledge and job competencies, but the ability to communicate and coordinate effectively via teamwork. This is critical because the supply chain involves multiple companies across the countries.

Two crucial competencies that a supply chain manager faces in a rapidly changing environment are communication and teamwork. Prajogo and Sohal (2013) and Essex et al. (2016) concurred that communication and teamwork were critical domains for a competent supply chain professional in facing future business challenges. The ability to communicate with others is critical for practitioners (Gammelgard and Larson, 2001). Good communication and negotiating skills means that they can connect with other businesses, suppliers and customers (Wu et al., 2013; Cotrill, 2010). Indeed, Barhem et al. (2011) and Tabassi et al. (2016) believed that among the most important competencies for a successful supply chain manager were good communication skills. Additionally, however, supply chain managers should be able to integrate, communicate and analyze financial performance, maintain good industry and customer relations and understand regulations and laws from international perspective (Wu et al., 2013).

A dearth of studies exists in both supply chain and strategic human resource management literature with respect to a lack of a proper understanding of supply chain integration and responsiveness of supply chain managers. It leads to lack of resource to design and delivery of proper technical and strategic training for supply chain managers. This study will extend the literature by utilizing the competency-based theory to investigate the perceived understanding and communication capabilities of supply chain managers.

Conducing more comprehensive study to develop programs that lead to the preparation of more competent supply chain manager is now more necessary than ever before. In rapidly globalizing economies, supply chain managers must be able to quickly identify and react to the marketplace, customer needs and environmental changes. Especially with respect to dealing with routine activities regarding cross-functional activities in a company and interorganizational activities in the global context, supply chain managers should be able to cope 
with integration and be responsive to supply chain requirements. Effective communication and teamwork will come after the supply chain manager has achieved technical competencies, knowledge and task contextual. The supply chain manager must be proficient in technical competencies including how to assess the integration and responsiveness of supply chain networks. Therefore, supply chain integration (SCI) and supply chain responsiveness (SCR) are among the key activities involved in supply chain process that supply chain managers must master (Wu et al., 2006).

Both SCR and SCI are activities in SCM that are closely related to the interactions of people within a company or people in an inter-organizational context. Ghosh et al. (2014) defined SCR as the ability to react to sudden or immediate changes in the marketplace and responding to customer needs in a reliable and timely manner. SCR is an issue with which supply chain manager in a global context must deal (Prajogo and Sohal, 2013), and SCI has become the centerpiece of today's SCM (Huo et al., 2015). In their daily operation activities, supply chain managers should master communication and teamwork competencies because the successful implementation of SCI relies on human resources (Bendoly et al., 2006). Unfortunately, many scholars have neglected the role of human resources in SCI (Sweeney, 2013; Ellinger and Ellinger, 2014). From the HR perspective, two major challenges that a supply chain manager faces during supply chain integration are collaboration across companies that involves supply chain networks and real-time communication. Effective communication and teamwork are the main domains of soft factors influencing supply chain integration. Customer satisfaction, flexibility, agility and operational performance will impact the effective implementation of a supply chain strategy. If a supply chain manager is not competent and a company is unable to cope with market requirements, then these deficiencies potentially will lead to business losses.

This paper sheds light on emerging research areas of SCM which investigate the supply chain manager's competency. This paper is designed to extend the literature on SCM talent development by looking at that development from a human resource perspective. The intersection of SCM and HR will open a new field of research especially in conceptualization of the model emphasizing the management of SCI and SCR to improve the communication skills and teamwork competency of supply chain managers. Thus, this paper makes a practical contribution on the drivers of supply chain manager competency. Supply chain managers can need to enhance the perceived understanding of supply chain integration (PUSCI) and perceived understanding of supply chain responsiveness (PUSCR) as key SCM practice success factors. SCI and SCR are critical contents to be included in the design of training and development programs of a professional supply chain manager. If a supply chain manager does not have the ability to understand how a company's operation can be integrated strategically, the supply chain manager is unable to communicate with other supply chain networks across companies, then this inability will impact the overall supply chain performance.

\section{Review of the literature}

SCM has gained popularity because of intensified global competition and value-seeking initiatives (Fernando and Saththasivam, 2017). The essence of supply chain is a business process, comprising technical, operational and social integration (Elbanna, 2007). Technical integration is hardware and software integration, operational integration is streamlining the business processes and social integration in the ability to work in teams, groups and as individuals, taking care of technical and operational integration (Ghosh et al., 2014).

$\mathrm{SCI}$ is the degree to which a firm strategically collaborates with its supply chain partners and collaboratively manages intra- and inter-organization processes (Ghosh et al., 2014) to achieve effective and efficient flows of products and services, information, money and 
EJMBE 30,2

194

decisions to provide maximum value to the customer (Flynn et al., 2010). Business costs can be reduced by conducting collaborative integration between supply chain partners through the better alignment of incentives and reward systems to minimize inefficient resource utilization and non-value adding activities (Ellinger and Ellinger, 2014).

The ability to understand the integration and teamwork between supply chain participants has become necessary in SCM practices (Sweneey, 2013). Integration means sharing information, resources and risks, proactive communication, joint development of supply chain processes and coordinating plan and decision-making within and among supply chain participants. Teamwork means developing a co-operative relationship between supply chain participants as a requirement in creating customer value. To achieve a competitive advantage in the marketplace, a unified effort among an interdependent supply chain's participants is required (Ellinger and Ellinger, 2014).

The effectiveness of a company's supply chain and how fast that supply chain reacts to the rapidly changing marketplace can create competitive advantage for a firm and the ability of a firm's supply chain to respond is called SCR (Kim et al., 2013; Ghosh et al., 2014). Most previous scholars have highlighted that the scope of supply chain responsiveness mostly resides in the network of players operating the supply chain, which represents the ability of a company to respond to market changes whether these come from company itself, supply chain partners and how their collaborative effort to overcome the changes (Squirre et al., 2009).

SCI and SCR are SCM practices that must face rapid changes in the market as the consequence of globalization. Both activities rely on the ability of a person to manage the technical and managerial challenges in an organization. Previous scholars have found a shortfall in SCM talent management to do so, caused by lack of understanding by senior level managers about the importance of SCM strategy, so that priority placed on improving SCM resources remains limited (Ellinger and Ellinger, 2014).

To resolve the SCM talent shortfall, scholars must reconsider the development of SCM personnel with the necessary skills and business-related competencies in managing strategically important and complex supply chain processes (Cotrill, 2010; Christhoper, 2012). Thus, developmental approaches to overcome the SCM talent shortfall are required (Ellinger and Ellinger, 2014), especially for supply chain managers who hold a strategic function in a company and who hold critical position for business decision-making. This study defines PUSCI as the ability of a supply chain manager to understand how to create a network with strategic supply chain partners for business integration in four functional areas including procurement, production, inventory and distribution. The PUSCR is defined as the ability of a supply chain manager to understand the variety of customer's needs and the ability to respond to unpredictable changing market demands using qualitative and quantitative metrics.

In facing rapidly changing markets, companies must be able to respond quickly and effectively by integrating intra- and inter-organizational supply chain partners. Supply chain managers who have effective communication and teamwork competencies can be expected to resolve challenges. To achieve those competencies, supply chain managers must be provided with qualified training and development programs from HR departments, and competencybased training and development must be conducted continuously. To conceptualize the relationship among variables in the research model, this study extended the task-contextual competency model (Ajayi et al., 2016). The proposed extended model was designed to conceptualize competency-based training and development to create a qualified manager. The research model used was based on competency-based training and competency theory (McClelland, 1973; Boyatzis, 1982; Spencer et al., 1993).

The definitions of competency theory include knowledge, skills and attitudes that allow individuals to express job behavior and achieve that which an organization needs to provide a 
particular performance for each workplace (McClelland, 1973; Meethongjan and Tachpetpaiboon, 2015). The competency-based approach to human resource management has become integral during the last thirty years, the competency theory involving some pillars including knowledge, skills, attitude, traits and behaviors that allow individuals to perform tasks within a specific function or job (Boyatzis, 1982). Below are competencies and skills that must be mastered by a supply chain manager (Table 1).

The relationship between PUSCI and PUSCR

\section{Theoretical framework}

This study has conceptualized the SCM constructs based on the perceived understanding of the supply chain manager of SCI and SCR. The perceived understanding of SCI and SCR will lead to a competent supply chain manager who performs tasks proficiently and knowledgeably. This is in line with competency theory that posits if the supply chain manager has skills and knowledge of the SCI and SCR, then these will allow them to perform their tasks better. Thus, supply chain managers must have PUSCI and PUSCR to leverage the knowledge and task skills proficiency to communicate and develop teamwork effectively to manage the complexity of global supply chains. Figure 1 shows the theoretical framework research model. Based on the review of literature, this study proposed research hypotheses that seek empirical justification.

According to Cahn (1983), the perception of understanding is part of an individual's assessment of his or her success based on his/her understanding of certain interactions and experience. The feeling of being understood about something will then lead to the ability to convey the information or solution to others. Effective communication assists an individual with working in a team effectively. Perceived understanding is critically essential when an individual needs to be capable of handling technical competency. Viitala (2005) defined technical competencies as the managers' ability to handle procedures, tools and methods in a specialized field that usually represent skills and knowledge. Suttiwatnaruput et al. (2014) found that managerial skills, technical knowledge and application are among complementary drivers to achieve a higher level of supply chain integration. Thus, the implementation of supply chain integration needs technical competence, and one of critical domains for business performance improvement is SCI. Besides that, good communication is an enabler to mutual trust among the supply chain partners (Mandal and Sarathy, 2018). To integrate the business function including business processes and information among supply chain networks, the strong commitment of stakeholders and resource allocation from management is needed. A perceived high level of understanding on how the supply chain integration can be implemented successfully will help a supply chain manager to communicate effectively with a team. The link from one variable to another is stated in H1.

H1. The perceived understanding of supply chain integration by supply chain managers will have a positive and significant impact on communication and teamwork.

The complexity of supply chain network across countries has increased the demand for better SCM practices. Christopher (2012) argued that companies' ability to cope with supply chain complexity will impact on business competitiveness improvement. A supply chain manager needs to build responsive supply chains to meet the market demands. Lau and Lee (2000) posit that organizations restructure and streamline using knowledge work teams, and information flow in the supply chain can improve company capacity to become more responsive to changing market demands. The company can use a range forecast, supply capacity, visibility and analysis to build responsive supply chains. To accommodate market demands, a range forecast is useful to foresee price, product/service varieties and supply volume. The supply capacity, visibility and analysis can provide the risk mapping, monitoring and risk mitigation strategy to manage the bullwhip effect (demand fluctuation), 


\begin{tabular}{l} 
EJMBE \\
30,2 \\
\\
$\mathbf{1 9 6}$ \\
\hline
\end{tabular}

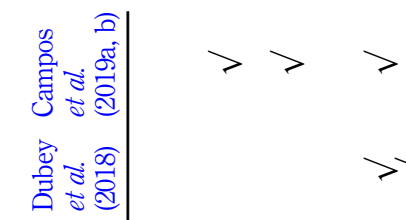

骨

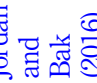
壱

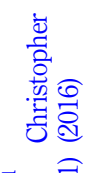
胥急 告 䨌䒕 离 $\approx$ 뙤 $\div$ 苞宗 ตัป ชิ

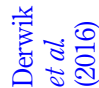

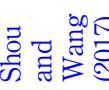
윰 증 능 㐫 㞼方

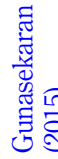

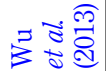

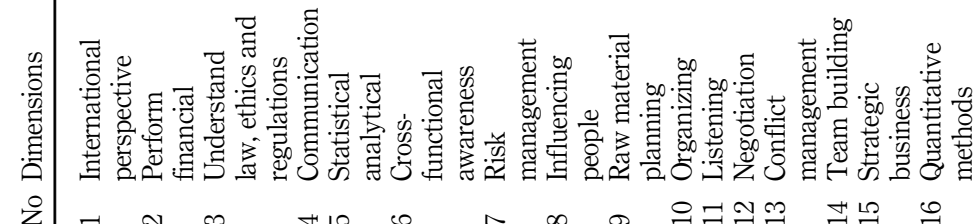

Table 1

Supply chain manager competencies and skills

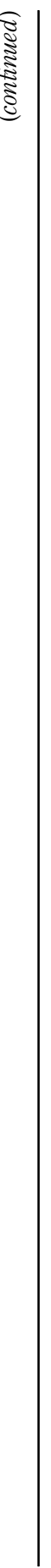




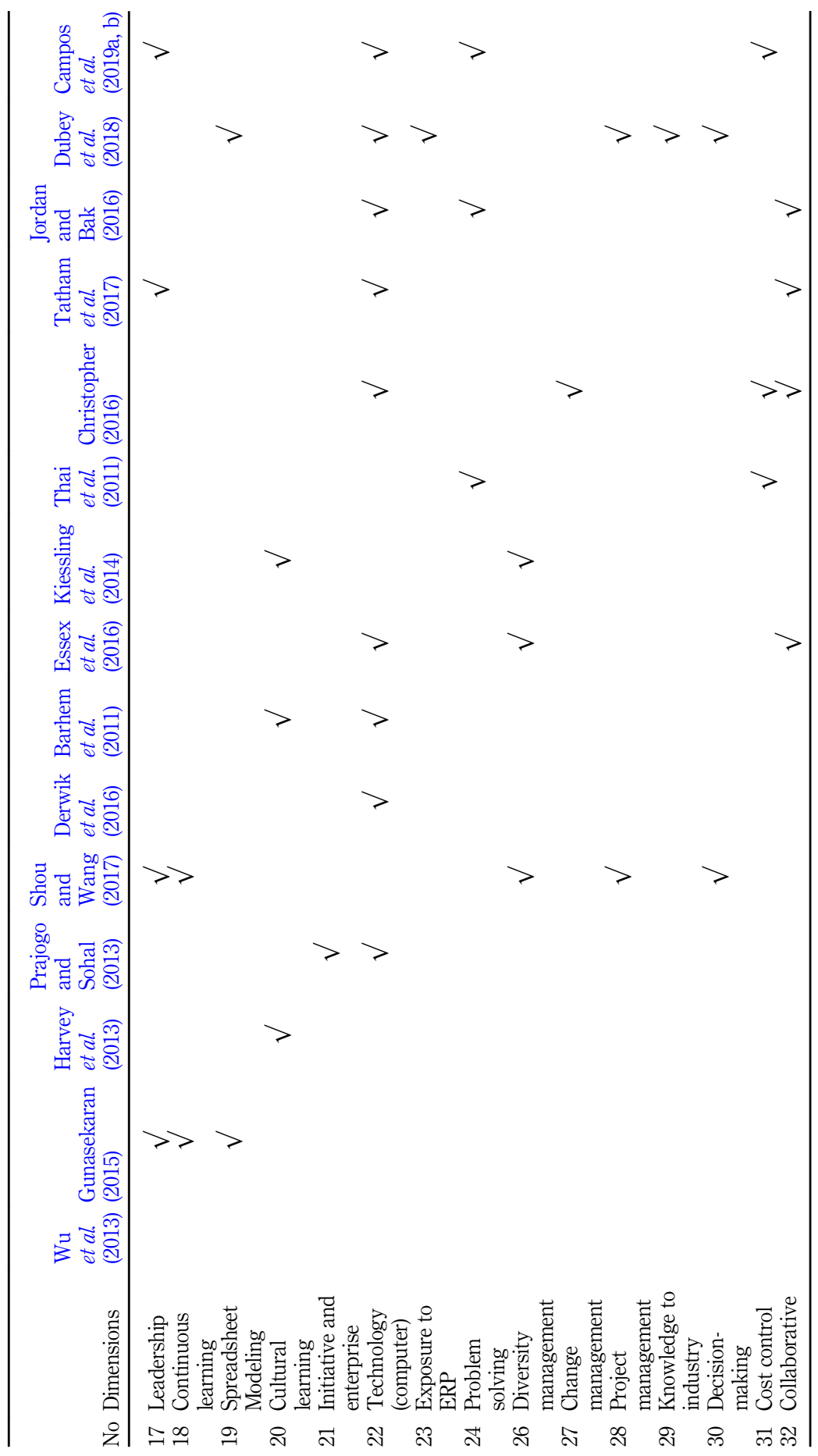

The relationship between PUSCI and PUSCR

197

Table 1. 
EJMBE 30,2

198

Figure 1.

Theoretical framework

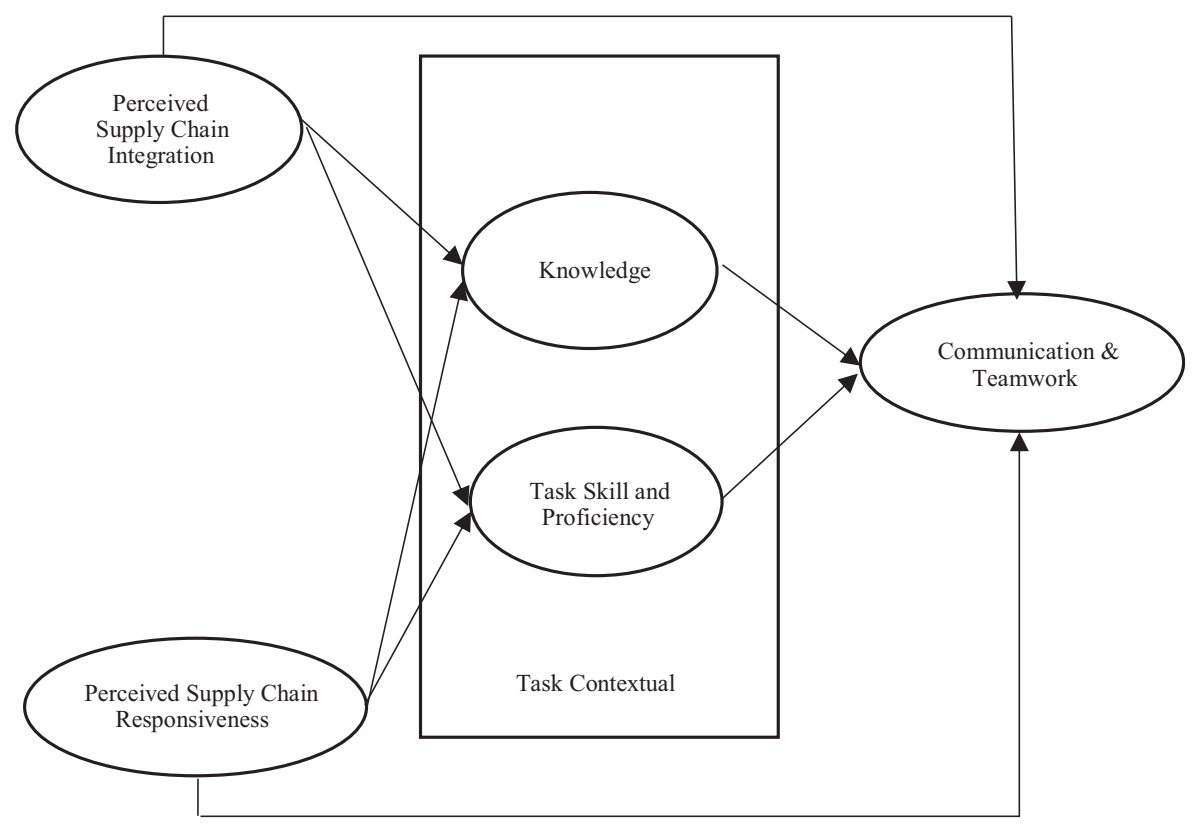

supplier risk etc. The collaboration among supply chain networks will assist a supply chain manager in designing a supply chain strategy that is able to respond to market demand that fits with a firm's resources. According to Katiyar et al. (2018), a common issue for firms is that they are sometimes unaware of the appropriate performance metrics for SCM. Supply chain responsiveness is part of operational performance, and the supply chain should be capable of being responsive. The supply chain professionals need knowledge of a broad range of technologies to respond and communicate both intra-company and inter-company (Prajogo and Sohal, 2013). An understanding of a supply chain manager about how fast they should respond to market demand is based on how good they can use communication skills and technologies. If they are capable of communicating a request from the market to supply chain networks, then the established teamwork will deliver fast and reliable support to the market. Thus, $\mathrm{H} 2$ is stated as follows.

H2. The perceived understanding of supply chain responsiveness by supply chain managers will have a positive impact on communication and teamwork.

Understanding the concept and practice of supply chain integration will assist a supply chain manager in continuously improving firm operational performance to achieve integration at both the strategic and tactical level, and an effective SCM framework must coordinate all the scheduling and rescheduling across supply chain mechanisms (Parwez, 2016). Truly understanding best practices for supply chain integration is not an easy task because supply chain integration encompasses technical and managerial domains. The technical domains cover the horizontal (the same level of chains) and vertical integration (different levels of chains) needed to understand the outsourcing process and supply chain activities. Enabling supply chain integration is a dynamic process, if need be, supply chain designs can be reviewed and modified (Bhaumik, 2015). Managerial competency will focus on accessibility to utilize firm resources for supply chain integration and work closely with supply chain networks. Only by understanding the concept will a supply chain manager be able to have 
knowledge to link global networks into a closer working relationship. Thus, this paper hypothesized in H3a.

H3a. The perceived understanding of supply chain integration by supply chain managers has a positive and significant impact on knowledge. and PUSCR

A supply chain manager needs to design supply chain integration to reduce costs and improve firm flexibility. The different development level of supply chain integration has different capabilities for cost reduction (Kim, 2006). The idea of supply chain integration is to bring all the networks involve in the supply chain to work closely together. The outcome is expected to reduce costs and improve productivity. The supply chain manager is expected to design, supply chain integration that fit with business strategy. There are two options that a supply chain manager can consider to design the supply chain integration for cost reduction. The first option is horizontal integration. The supply chain manager can bring all the vendors/ suppliers into the same level of the chain. The cost reduction can be achieved if the all networks can be integrated into the similar level with the central processing unit to control raw materials supply price and quantity. Vertical integration can be considered as the second option. To reduce cost, the supply chain manager can design the movement of procurement from the different tier or level of the chain. This is can tighter coordination with other supply chain networks by purchase materials or supply of semi-finished product ahead before the company. Vertical integration will assist the firms to handle the movement from upstream and downstream level of the supply chain.

A capable supply chain manager will be able to achieve integration among supply chain networks across the countries if their have sufficient task skill and proficiency. Despite the supply chain managers have rich analytical skills and the ability to evaluate and select the supply chain partners, the lack experience to deal with soft skills to support the effective team building still needs improvement. The soft skills like empathetic and intuitive (right brain) are required task skills and proficiency for supply chain manager to achieve successful supply chain integration (Christopher, 2012). Task skills and proficiency in the implementation of supply chain integration will help a supply chain manager to leverage firm performance and assist a firm to compete effectively. One reason for implementing supply chain integration is to reduce costs. A firm needs to find best way to leverage supply chain competencies, firm resources and skills across its supply chain network (Mohammaddust et al., 2017). An understanding of how to coordinate supply chain integration will help a supply chain manager to improve his/her task skill and proficiency in handling the complexity of supply chain. To solve the supply chain integration issues, a supply chain manager need to be creative. According to Sia and Appu (2015), the freedom given to an employee has a significant impact the on employee creativity. Thus, this paper postulated $\mathrm{H} 3 \mathrm{~b}$ as follows.

$H 3 b$. The perceived understanding of supply chain integration by supply chain managers will have a positive and significant impact on task skill and proficiency.

Supply chains frequently encounter business issues that a need quick response with the support of decision-making tools regarding uncertain demand, raw materials price, availability of production capacity and costing, logistics, custom and distribution channels. To increase firm level responsiveness, supply chain managers often collect useful information regarding the drivers, which affect both demand and supply (Williams et al., 2013). A critical part of the success of supply chain implementation resides in the knowledge and experience of $s$ supply chain manager to respond to market demand wisely. According to Walters and Rainbird (2004), the SCM should be driven by the market and not driven by suppliers. A combination of knowledge, skills and work experience deals with market demand are critical factors to create the competencies required for supply chain 
EJMBE 30,2

managers to excel in their careers (APICS, 2014). A supply chain manager is considered a being in a strategic position in a firm and must exhibit the required leadership skills and behavior. Thus, supply chain managers should act like leaders and managers. Their leadership skills are required to develop human capital in supply chain networks. To some extent these leadership behaviors have effects on employees' skills, knowledge, capability and commitment (Birasnav, 2013). Thus, this paper posits the following hypothesis in H4a.

$H 4 a$. The perceived understanding of supply chain responsiveness by supply chain managers will have a positive and significance impact on knowledge.

Understanding the best practices about how to respond market demand will lead to ability of a supply chain manager to deliver task skill and proficiency. Williams et al. (2013) said that supply chain managers need find clarity with respect to what information is actually valuable. Their findings indicated that a strategy for achieving supply chain responsiveness requires a dual-pronged approach aligns increased visibility of valuable information with extensive information processing capabilities. In turn, a greater level understanding of supply chain managers on how to respond market demand and supply will help to leverage their task skills and proficiency to design an integrated information flow and handle the bullwhip effect. Supply chain responsiveness refers to the firm ability to provide the right product at the right time to the customer (Moyano-Fuentes et al., 2016). Thus, hypothesis H4b is posited as follows.

H4b. The perceived understanding of supply chain responsiveness by supply chain managers will have a positive and significant impact on task skill and proficiency.

Knowledge that was derived from the ability to understand supply chain integration and responsiveness will be effective if the manager can communicate to with supply chain partners using people skills and establish teamwork among supply chain network. Körner et al. (2016) postulated that knowledge integration come from the process of building shared mental models. Knowledge integration has been confirmed to positively affect teamwork and team performance. The supply chain managers should share their supply chain knowledge and practice open communication. According to Rubel et al. (2017), open communication will lead to employee commitment in a long-lasting relationship. The relationship among variables is postulated in the H5.

H5. Knowledge will have a positive and significant impact on communication and teamwork.

Supply chain managers are required to have task skill and proficiency in handling supply chain complexity, which often with multiple channels and the conflicting business strategy with profit-cost analysis, responsiveness and service level, among others (Bhaumik, 2015). Supply chain managers need to demonstrate their leadership capabilities by practicing effective communication and teamwork. The task skills and proficiency required will be more challenging if supply chain managers are required to coordinate supply chain networks that have different cultures and languages. Supply chain managers are role models in a firm and have a responsibility to serve as a coach and mentor. Hypothesis $\mathrm{H} 6$ will be stated below.

H6. Task skill and proficiency will have a positive and significant impact communication and teamwork.

Knowledge is among the most critical resources to compete in a market based on a knowledge economy (Pillania, 2006). Sufficient knowledge that can be derived from an understanding of supply chain integration will help in leveraging resource utilization to integrate the upstream and downstream supply chain networks with good communication 
skills and teamwork. Knowledge about supply chain integration will be conveyed properly to multiple channels, yet solid teamwork is only established if a supply chain manager can use people skills to coordinate supply chain networks and achieve mutual goals. Thus, H7a below is posited.

$H 7 a$. There is a mediating effect of knowledge on the relationship between perceived understanding of supply chain integration and communication and teamwork.

The relationship between the PUSCR in handling market volatile and the ability of a supply chain manager to communicate to a team will be greater if the knowledge of a supply chain manager is sufficient to immediately make a strategic decision. The supply chain managers need to quickly respond to market demand and requirements with a better understanding of supply chain responsiveness concepts and tools. The intervening variable of knowledge will leverage the link from understanding responsiveness concept in supply chain to effective communication and teamwork. According to Mandal and Sarathy (2018), the adaption on the rapid responses to environmental changes is a prerequisite for supply chain resilience. In fact, the adaptation requires good communication. The paper postulated H7b as follows:

H7b. Knowledge mediates the relationship between perceived understanding of supply chain responsiveness and communication and teamwork.

The ability to understand the concept of supply chain integration will be helpful in effectively communicating supply chain teamwork across sectors and countries, if supply chain managers have a greater capacity to grasp the task skills and proficiency needed to manage the strategical and operational levels. Task skills and proficiency will mediate the relationship perceived understanding integration and communication in teamwork, and if managers truly understand how supply chain integration will be established via an understanding can be garnered from the facts and figures at hand. It will work if supply chain managers have the ability to track critical events and activities in supply chain sharing systems. Parwez (2016) highlighted that SCM systems are supporting tools to assist a supply chain managers handling abnormal business trends. As events unfold, the system can track critical events and activities and will out alerts and messages to notify appropriate managers to take corrective actions. Supply chain managers should communicate the unexpected event from a market requirement to the supply chain team to gain business sustainability. Thus, hypothesis $\mathrm{H} 8 \mathrm{a}$ is posited.

H8a. There will be a mediating effect of task skill and proficiency on the relationship between perceived understanding of supply chain integration and communication and teamwork.

Being quickly responsive to market demand will reduce negative impacts to business performance, and supply chain managers are expected to have sufficient task skill and proficiency to manage inaccurate forecasting in the market. Furthermore, the task skills and proficiency of supply chain managers can mediate the relationship between understanding of supply chain responsiveness on effective communication and teamwork. If these task skills and proficiency do not react to market demand wisely, this will yield supply chain inefficiencies as supply chain managers will wrongly predict market demand and fluctuations. The ability to respond to the uncertainty of market demand can be developed if supply chain managers can create atmosphere of open participation for its supply chain members. In turn, open participation can create opportunity for sharing and exchanging valuable risk management knowledge and expertise (Mandal and Sarathy, 2018). The connection between variables is stated in $\mathrm{H} 8 \mathrm{~b}$. 
EJMBE 30,2
H8b. There is a mediating effect of task skill and proficiency on the relationship between perceived understanding of supply chain responsiveness and communication and teamwork.

\section{Methodology}

The data were collected using a survey questionnaire that was mailed to the 413 supply chain managers of global manufacturing companies in Indonesia. The supply chain managers were key informants from managerial positions (Fernando et al., 2015). The survey was restricted to global manufacturing companies that were actively conducting export and import activities, including raw materials, semi-finished products and final products. The data collection procedure involved several steps. The first was contacting the companies to ensure their interest and that they met the survey requirements and to see if they were interested and would agree to participate, a questionnaire was mailed with a follow-up contact. The questionnaires were sent to 413 companies who agreed to participate. The companies were given three weeks to respond the survey with follow up a procedure. However, 209 respondents unable to meet the deadline given due to a hectic workload, and 204 useable responses were ultimately collected for a response rate of about $49 \%$. The survey instrument used a 5-point Likert-type scale with answers ranging from 1 strongly disagree) to 5 (strongly agree).

\section{Data}

More than one-half of the respondents were male (60.8\%), and the rest were female $(39.2 \%)$. As for age, the majority of the respondents were between 41 and 45 years old $(43.6 \%)$, whereas other respondents were more than 45 years old (29.9\%), 35-40 years old (21.6\%) and less than 35 years old (4.9\%). Regarding the company profile, the sample represented a wide variety of industries, food, beverage and tobacco comprised $21.6 \%$, textile and garment/ leather goods and footwear (19.6\%), automotive and heavy machinery $(15.2 \%)$, cement and non-metal minerals/basic metal products $(12.3 \%)$, fertilizer and agriculture $(10.3 \%)$, information technology and telecommunications/electrics and electronics/green technology/renewable energy $(8.3 \%)$ and chemical and rubber products and paper and printing products/timber and forest products $(6.4 \%)$. Most of the companies imported their raw materials $(38.6 \%)$ from China and India. About $68.6 \%$ sold their products to Asian, the United States, Europe and Middle East counties.

Construct validity. To test construct validity, Hair et al.'s (2017) procedure was used to ensure that the data were suitable for structural equation modeling (SEM) with partial least square (PLS) statistical software. SmartPLS was used to analyze the data collected for this study (Fernando et al., 2018). Construct validity helped to ensure that items underlying the constructs of an instrument were derived from an extensive review of relevant literature and evaluation by academicians or practitioners (Hair et al., 2017). Convergent validity tested the degree to which multiple items that measured the same concept agreed with that concept (Hair et al., 2017). Hair et al. (2017) suggested using factor loading, composite reliability (CR) and average variance extracted (AVE) to access convergent validity.

The assessment results of convergent validity and CR are given in Table 2. Table 2 indicates that all the outer loadings were greater than 0.7 , while the value of average variance extracted (AVEs) were greater than 0.5 , and CR values were more than 0.7. Therefore, convergent validity and $\mathrm{CR}$ of construct are considered satisfactory, which means that the research model is valid and reliable.

In addition to convergent validity and $\mathrm{CR}$, discriminant validity measures the degree to which items differentiate among constructs or measure distinct concepts. It examines the 


\begin{tabular}{lccccc}
\hline Measurement items & CT & $K$ & SCI & SCR & $S$ \\
\hline 1 & 0.895 & 0.850 & 0.835 & 0.746 & 0.832 \\
2 & 0.890 & 0.835 & 0.789 & 0.745 & 0.922 \\
3 & 0.886 & 0.798 & 0.783 & 0.867 & 0.893 \\
4 & 0.796 & 0.757 & 0.804 & 0.903 & 0.912 \\
5 & 0.901 & 0.750 & N/A & N/A & 0.816 \\
AVE & 0.764 & 0.638 & 0.645 & 0.670 & 0.768 \\
CR & 0.942 & 0.898 & 0.879 & 0.890 & 0.943
\end{tabular}

The relationship between PUSCI and PUSCR

912

0.816

0.943

Note(s): CT = Communication and Teamwork; $K=$ Knowledge; PUSCI = Perceived Understanding of Supply Chain Integration; PUSCR = Perceived Understanding of Supply Chain Responsiveness; $S=$ Skill; $\mathrm{N} / \mathrm{A}=$ Not Applicable (SCI \& SCR only have 4 measurement items)

Table 2. Convergent validity

\begin{tabular}{|c|c|c|c|c|c|c|}
\hline & CT & $K$ & PUSCI & PUSCR & TP & \\
\hline \multicolumn{7}{|l|}{ CT } \\
\hline$K$ & 0.381 & & & & & \\
\hline PUSCI & 0.218 & 0.466 & & & & \\
\hline PUSCR & 0.112 & 0.340 & 0.245 & & & \\
\hline $\mathrm{TP}$ & 0.349 & 0.273 & 0.149 & 0.315 & & Discriminant validity: \\
\hline \multicolumn{7}{|c|}{$\begin{array}{l}\text { Note(s): CT = Communication and Teamwork; } K=\text { Knowledge; PUSCI = Perceived Understanding of } \\
\text { Supply Chain Integration; PUSCR = Perceived Understanding of Supply Chain Responsiveness; } S=\text { Skill }\end{array}$} \\
\hline
\end{tabular}

correlation between the measures of potentially overlapping constructs. Items should load more strongly on their own constructs in the model and the average variance shared between the construct and other constructs (Compeau et al., 1999). To test the discriminant validity, this study used the Heterotrait-Heteromethod (HTMT) correlation. The result of HTMT values is shown in Table 3 . The table indicates that the highest HTMT values was 0.466 which is lower than the threshold value of 0.850 . Additionally, based on PLS bootstrapping, the HTMT confidence interval was not zero. Thus, discriminant validity was established, and the measurement model has adequate construct validity.

Hypothesis testing. The path coefficient analysis was used to measure the path coefficient sizes and determine if relationship among the variables was statistically significant. The path coefficient is analyzed in two steps in PLS path modeling. The first step is to conduct the iterative algorithm that solves the blocks of the measurement model. Once a satisfactory measurement is obtained, then the analysis executes the second step. This step is to test the structural model validity and fit by determining the significance of path coefficients. The bootstrap resamples made up the number of sample drawn in the bootstrapping procedure and values must be higher than the number of bootstrap cases (204 cases). In bootstrapping, critical t-values can be generated to test the statistical significance of the path coefficient at $* p<0.10(t$-value $=1.282), * * p<0.05(t$-value $=1.645)$ and $* * * p<0.01(t$-value $=2.326)$ confidence level. This study used a multiple regression analysis with the consistent PLS bootstrapping in the SmartPLS 3.2.9 (Fernando et al., 2019).

According to Greenwald et al. (1996), p-values are a meaningful common language translation for statistical test. These values provide a measure of confidence in the replicability of null hypothesis rejections. According to Hair et al. (2014), the most commonly used $t$ critical values are: (1) two-tailed tests (non-directional) that are greater than 2.57, 1.96 and 1.65 for significance levels of 1,5 and $10 \%$ and (2) one-tailed tests (one-way, positive 


\begin{tabular}{|c|c|c|c|c|c|c|c|}
\hline & \multirow[b]{2}{*}{ Hypothesis } & \multirow[b]{2}{*}{ Relationship } & \multirow[b]{2}{*}{ Std. Beta } & \multirow[b]{2}{*}{ Std. Deviation } & \multirow[b]{2}{*}{$t$-values } & \multicolumn{2}{|c|}{$\begin{array}{l}\text { Confidence interval } \\
\text { bias corrected }\end{array}$} \\
\hline & & & & & & $2.50 \%$ & $97.50 \%$ \\
\hline \multirow[b]{4}{*}{204} & H1 & $\mathrm{PUSCI} \rightarrow \mathrm{CT}$ & 0.054 & 0.086 & 0.631 & -0.108 & 0.221 \\
\hline & $\mathrm{H} 2$ & $\mathrm{PUSCR} \rightarrow \mathrm{CT}$ & 0.277 & 0.068 & $2.372^{*}$ & 0.142 & 0.401 \\
\hline & H3a & PUSCI $\rightarrow K$ & 0.355 & 0.059 & $5.999 *$ & 0.233 & 0.456 \\
\hline & $\mathrm{H} 3 \mathrm{~b}$ & $\mathrm{PUSCI} \rightarrow \mathrm{TP}$ & 0.080 & 0.066 & 1.203 & -0.044 & 0.213 \\
\hline \multirow{9}{*}{$\begin{array}{l}\text { Table } 4 . \\
\text { Summary of } \\
\text { hypothesis testing PLS } \\
\text { path model }\end{array}$} & $\mathrm{H} 4 \mathrm{a}$ & PUSCR $\rightarrow K$ & 0.239 & 0.058 & $4.140^{*}$ & 0.099 & 0.325 \\
\hline & $\mathrm{H} 4 \mathrm{~b}$ & PUSCR $\rightarrow$ TP & 0.256 & 0.069 & $3.710^{*}$ & 0.120 & 0.386 \\
\hline & H5 & $K \rightarrow \mathrm{CT}$ & 0.310 & 0.072 & $4.271 *$ & 0.147 & 0.432 \\
\hline & $\mathrm{H} 6$ & $\mathrm{TP} \rightarrow \mathrm{CT}$ & 0.290 & 0.066 & $4.410 *$ & 0.158 & 0.411 \\
\hline & $\mathrm{H} 7 \mathrm{a}$ & $\mathrm{PUSCI} \rightarrow K \rightarrow \mathrm{CT}$ & 0.110 & 0.035 & $3.179 *$ & 0.050 & 0.178 \\
\hline & $\mathrm{H} 7 \mathrm{~b}$ & $\mathrm{PUSCR} \rightarrow K \rightarrow \mathrm{CT}$ & 0.074 & 0.027 & $2.733^{*}$ & 0.022 & 0.128 \\
\hline & $\mathrm{H} 8 \mathrm{a}$ & $\mathrm{PUSCI} \rightarrow \mathrm{TP} \rightarrow \mathrm{CT}$ & 0.023 & 0.021 & 1.107 & -0.010 & 0.074 \\
\hline & $\mathrm{H} 8 \mathrm{~b}$ & $\mathrm{PUSCR} \rightarrow \mathrm{TP} \rightarrow \mathrm{CT}$ & 0.074 & 0.029 & $2.573^{*}$ & 0.026 & 0.139 \\
\hline & \multicolumn{7}{|c|}{ Note(s): $* p<0.05$} \\
\hline
\end{tabular}

direction) that are greater than 2.33, 1.65 and 1.28 for significance levels of 1,5 and $10 \%$, respectively (Hair et al., 2014). This study used a one-tailed ( $t$-value $>1.645$ ) significant level.

The results of the PLS analysis for the research model are presented in Figure 1 and Table 4. Bootstrapping with 5,000 samples was used to evaluate the standard error and $t$ values of the path coefficients (Hair et al., 2014). The result in Table 3 showed that, for the direct effect of the hypothesized positive relationship between PUSCR, a direct relationship existed on supply chain manager's communication and teamwork competency (H1, path coefficient $=0.277, p<0.05$ ), between knowledge and supply chain manager's communication and teamwork competency ( $\mathrm{H} 5$, path coefficient $=0.310, p<0.05$ ), between task skill and proficiency and supply chain manager's communication and teamwork competency ( $\mathrm{H} 6$, path coefficient $=0.290, p<0.05$ ). Thus, these hypotheses were supported. This indicates that global manufacturing companies need to improve their SCR, knowledge and task skill and proficiency to achieve better supply chain manager's communication and teamwork competency.

A positive relationship was also found in the relationship between SCI and knowledge (H3a, path coefficient $=0.277, p<0.05$ ), between SCR and knowledge (H4a, path coefficient $=0.239, p<0.05$ ). Thus, these hypotheses are supported. This indicated that to achieve a supply chain manager's knowledge, global manufacturing companies should improve their SCI and SCR. Moreover, the hypothesized positive relationship between SCR and task skill and proficiency $(\mathrm{H} 4 \mathrm{~b}$, path coefficient $=0.256, p<0.05)$ is supported, indicating that global manufacturing companies need to improve their SCR to achieve a better task skill and proficiency among supply chain managers.

Meanwhile the result for hypothesized indirect effect that significant knowledge would mediate the relationship between SCI and SCR with respect to communication manager's communication and teamwork competency (H7a, path coefficient $=0.110, p<0.05$; H7b, path coefficient $=0.074, p<0.05$ ) was supported. Task skill and proficiency have a significant mediating effect in the relationship between SCR and supply chain manager's communication and teamwork competency (H8b, path coefficient $=0.074, p<0.05$ ), while the mediation of the relationship between SCI and supply chain manager's communication and teamwork competency (H8a, path coefficient $=0.074, p<0.05$ ) was not supported. 


\section{Discussion}

SCR has the greatest influence on this model, which established a relationship with supply chain manager's communication and teamwork competency. SCM also positively and significantly influenced knowledge and task skill and proficiency. This result implies that an understanding of SCR led to an improvement in a supply chain manager's communication and teamwork competency, knowledge and task skill and proficiency. The positive relationship between analytical/communication skills and supply chain responsiveness was supported by Carr and Smeltzer (2000), and the results were consistent with Lorentz et al. (2013) that posited that SCR is needed to improve the competitiveness of global manufacturing companies in a global context. Therefore, a supply chain manager should understand the concept of SCR to meet market requirements and maintain relationship with partners. This might help especially in handling supply chain disruptions and cost reductions.

The perceived understanding of SCR mediates knowledge and task skill and proficiency and also mediated supply chain manager's communication and teamwork competency. This means that supply chain managers who have an understanding of SCR as part of the knowledge and skills required will be able to react and adapt quickly and effectively for sudden and rapid changes in the market or business environment and collaboratively and, thus, make some effort to resolve the issues. The results were consistent with previous findings such as Ghosh et al. (2014).

This study confirmed the findings by Prajogo and Sohal (2013) that perceived understanding of SCR is a critical component of SCM practices activities that supply chain managers should master and be embedded as a knowledge and skills. Nowadays, managing SCR in SCM practices has become a driver of competitive force to handle a turbulent marketplace (Melnyk et al., 2014). Supply chain managers should able to communicate changes in technology, currency exchange, costs, pricing and the quality of materials to the suppliers. Besides that, communicating SCR well to suppliers and business partners will escalate teamwork competency. A perceived understanding of SCR will help companies, suppliers and buyers to handle market turbulence in the local and global context.

In term of indirect effect, SCI showed different result. Of two SCI indirect effects, only one was positive and significantly linked to supply chain manager's knowledge. The results were in line Prajogo and Sohal (2013) that emphasized that PUSCI is needed as fundamental knowledge for a better supply chain professional. Understanding the concept and tools of SCI will make supply chain managers better able to integrate operational areas such as technical, operational and social facet on business processes. The company should improve global competencies, which are highly volatile and rapidly changing (Hui and Fernando, 2018). By having this knowledge, supply chain managers would be successful in managing these facets and able to ensure a business is better able to achieve its objectives and make correct decisions with uncertainty markets.

In term of direct paths, the PUSCI found to be insignificant with respect to task skill and proficiency, yet it had a significant relationship on knowledge enhancement thru an indirect path. The indirect relationship demonstrated that task skill and proficiency were not significantly related to leveraging the relationship between SCI and communication and teamwork. Therefore, a human resource department should design a SCI training program that relates to task skill and proficiency in handling global supply chain activities. The integration should coordinate effective communication and teamwork among supply chain networks. Managing supply chain networks and supplier involvement have become critical for businesses because they are the backbone of operations (Fernando et al., 2016). The findings were in line with the Esper et al.'s (2010) study that a company should establish SCI to create values for customer's using knowledge sharing, which connects supply chain networks including sourcing materials, production and market requirements. relationship between PUSCI and PUSCR

205 
EJMBE 30,2

\section{References}

Ajayi, S.O., Oyedele, L.O., Kadiri, K.O., Akinade, O.O., Bilal, M., Owolabi, H.A. and Alaka, H.A. (2016), "Competency-based measures for designing out construction waste: task and contextual attributes", Engineering Construction and Architectural Management, Vol. 23 No. 4, pp. 464-490.

APICS (2014), Supply Chain Manager Competency Model, APICS Supply Chain Managers Career Pack, Chicago, pp. 1-20.

Barhem, B., Younies, H. and Smith, P.C. (2011), "Ranking the future global manager characteristics and knowledge requirements according to UAE business managers' opinions", Education Business and Society: Contemporary Middle Eastern Issues, Vol. 4 No. 3, pp. 229-247.

Bendoly, E., Donohue, K. and Schultz, K.L. (2006), "Behavior in operations management: assessing recent findings and revisiting old assumptions", Journal of Operations Management, Vol. 24 No. 6, pp. 737-752.

Bhaumik, P.K. (2015), "Supply chain network design based on integration of forward and reverse logistics", Global Business Review, Vol. 16 No. 4, pp. 680-699.

Birasnav, M. (2013), "Implementation of supply chain management practices: the role of transformational leadership”, Global Business Review, Vol. 14 No. 2, pp. 329-342.

Boyatzis, R.E. (1982), The Competent Manager: A Model for Effective Performance, John Wiley \& Sons, New York.

Butt, A.S. and Ahmad, A.B. (2019), "Personal relationship and conflicts in supply chains: exploration of buyers and suppliers in Australian manufacturing and service sector", Benchmarking: An International Journal, Vol. 26 No. 7, pp. 2225-2241.

Cahn, D.D. (1983), "Relative importance of perceived understanding in initial interaction and development of interpersonal relationships", Psychological Reports, Vol. 52 No. 3, pp. 923-929.

Campos, D.F., de Andrade Lima, J.T. Jr, da Silva, A.B. and Fernandes, A.J. (2019a), "Professional competencies in supply chain management in the mid-sized supermarket sector in Brazil", Supply Chain Management: An International Journal, Vol. 24 No. 3, pp. 405-416.

Campos, P., Oviedo, J.L., Álvarez, A., Mesa, B. and Caparrós, A. (2019b), "The role of non-commercial intermediate services in the valuations of ecosystem services: application to cork oak farms in Andalusia, Spain”, Ecosystem services, Vol. 39, p. 100996.

Carr, A.S. and Smeltzer, L.R. (2000), "An empirical study of the relationships among purchasing skills and strategic purchasing, financial performance, and supplier responsiveness", Journal of Supply Chain Management, Vol. 36 No. 2, pp. 40-54.

Christopher, M. (2012), "Managing supply chain complexity: identifying the requisite skills", Supply Chain Forum: An International Journal, Vol. 13 No. 2, pp. 4-9.

Christopher, M. (2016), Logistics and Supply Chain Management, Pearson Education, Harlow.

Compeau, D., Higgins, C.A. and Huff, S. (1999), "Social cognitive theory and individual reactions to computing technology: a longitudinal study", MIS Quarterly, Vol. 23 No. 2, pp. 145-158.

Cottrill, K. (2010), Are You Prepared for the Supply Chain Talent Crisis?, MIT Center for Transportation and Logistics, Cambridge, MA, pp. 1-11.

Derwik, P., Hellström, D. and Karlsson, S. (2016), "Manager competences in logistics and supply chain practice", Journal of Business Research, Vol. 69 No. 11, pp. 4820-4825.

Dubey, R., Gunasekaran, A., Childe, S.J. and Papadopoulos, T. (2018), "Skills needed in supply chainhuman agency and social capital analysis in third party logistics", Management Decision, Vol. 56 No. 1, pp. 143-159.

Elbanna, A.R. (2007), "Implementing an integrated system in a socially dis-integrated enterprise: a critical view of ERP enabled integration", Information Technology and People, Vol. 20 No. 2, pp. 121-139. 
Ellinger, A.E. and Ellinger, A.D. (2014), "Leveraging human resource development expertise to improve supply chain managers' skills and competencies", European Journal of Training and Development, Vol. 38 Nos 1-2, pp. 118-135.

Esper, T.L., Ellinger, A.E., Stank, T.P., Flint, D.J. and Moon, M. (2010), "Demand and supply integration: a conceptual framework of value creation through knowledge management", Journal of the Academy of Marketing Science, Vol. 38 No. 1, pp. 5-18.

Essex, A., Subramanian, N. and Gunasekaran, A. (2016), "The relationship between supply chain manager capabilities and performance: empirical evidence", Production Planning and Control, Vol. 27 No. 3, pp. 198-211.

Fernando, Y. and Saththasivam, G. (2017), "Green supply chain agility in EMS ISO 14001 manufacturing firms: empirical justification of social and environmental performance as an organisational outcome", International Journal of Procurement Management, Vol. 10 No. 1, pp. 51-69.

Fernando, Y., Ng, H.H. and Walters, T. (2015), "Regulatory incentives as a moderator of determinants for the adoption of Malaysian food safety system", British Food Journal, Vol. 117 No. 4, pp. 1336-1353.

Fernando, Y., Wah, W.X. and Shaharudin, M.S. (2016), "Does a firm's innovation category matter in practising eco-innovation? Evidence from the lens of Malaysia companies practicing green technology", Journal of Manufacturing Technology Management, Vol. 27 No. 2, pp. 208-233.

Fernando, Y., Jabbour, C.J.C. and Wah, W.X. (2019), "Pursuing green growth in technology firms through the connections between environmental innovation and sustainable business performance: does service capability matter?", Resources, Conservation and Recycling, Vol. 141, pp. 8-20.

Fernando, Y., Walters, T., Ismail, M.N., Seo, Y.W. and Kaimasu, M. (2018), "Managing project success using project risk and green supply chain management: a survey of automotive industry", International Journal of Managing Projects in Business, Vol. 11 No. 2, pp. 332-365.

Flynn, B.B., Huo, B. and Zhao, X. (2010), "The impact of supply chain integration on performance: a contingency and configuration approach", Journal of Operations Management, Vol. 28 No. 1, pp. 58-71.

Gammelgaard, B. and Larson, P.D. (2001), "Logistics skills and competencies for supply chain management", Journal of Business Logistics, Vol. 22 No. 2, pp. 27-50.

Ghosh, A., Das, S. and Deshpande, A. (2014), "Effect of responsiveness and process integration in supply chain coordination”, IUP Journal of Supply Chain Management, Vol. 11 No. 1, p. 7.

Greenwald, A., Gonzalez, R., Harris, R. and Guthrie, D. (1996), "Effect sizes and p values: what should be reported and what should be replicated?", Psychophysiology, Vol. 33 No. 2, pp. 175-183.

Gunasekaran, A., Subramanian, N. and Rahman, S. (2015), Green Supply Chain Collaboration and Incentives: Current Trends and Future Directions, Vol. 74 No. 2, pp. 1-10.

Hair, J.F. Jr, Hult, G.T.M., Ringle, C. and Sarstedt, M. (2014), A Primer on Partial Least Squares Structural Equation Modeling (PLS-SEM), SAGE Publications, California.

Hair, J.F. Jr, Hult, G.T.M., Ringle, C. and Sarstedt, M. (2017), A Primer on Partial Least Squares Structural Equation Modeling (PLS-SEM), 2nd ed., SAGE Publications, Singapore.

Harvey, M., Fisher, R., McPhail, R. and Moeller, M. (2013), “Aligning global organizations' human capital needs and global supply-chain strategies”, Asia Pacific Journal of Human Resources, Vol. 51 No. 1, pp. 4-21.

Hohenstein, N.O., Feisel, E. and Hartmann, E. (2014), "Human resource management issues in supply chain management research: a systematic literature review from 1998 to 2014", International Journal of Physical Distribution and Logistics Management, Vol. 44 No. 6, pp. 434-463. 
EJMBE 30,2

\section{8}

Hui, H.Y. and Fernando, Y. (2018), "Improving competencies for the courier service industry in Malaysia”, Encyclopedia of Information Science and Technology, 4th ed., IGI Global, Pennsylvania, pp. 2802-2809.

Huo, B., Han, Z., Chen, H. and Zhao, X. (2015), "The effect of high-involvement human resource management practices on supply chain integration", International Journal of Physical Distribution and Logistics Management, Vol. 45 No. 8, pp. 716-746.

Jordan, C. and Bak, O. (2016), "The growing scale and scope of the supply chain: a reflection on supply chain graduate skills", Supply Chain Management: An International Journal, Vol. 21 No. 5, pp. 610-626.

Katiyar, R., Barua, M.K. and Meena, P.L. (2018), "Analysing the interactions among the barriers of supply chain performance measurement: an ISM with fuzzy MICMAC approach", Global Business Review, Vol. 19 No. 1, pp. 48-68.

Kattman, B.R. (2014), "In today's global environment organizational culture dominates national culture!", Benchmarking An International Journal, Vol. 21 No. 4, pp. 651-664.

Kiessling, T., Harvey, M. and Garrison, G. (2014), "The importance of boundary-spanners in global supply chains and logistics management in the 21st century", Journal of Global Marketing, Vol. 17 No. 4, pp. 93-115.

Kim, W.S. (2006), "Effects of supply chain management practices, integration and competition capability on performance", Supply Chain Management: An International Journal, Vol. 11 No. 3, pp. 241-248.

Kim, J. and McLean, G.N. (2015), “An integrative framework for global leadership competency: levels and dimensions", Human Resource Development International, Vol. 18 No. 3, pp. 235-258.

Kim, M., Suresh, N.C. and Kocabasoglu-Hillmer, C. (2013), "An impact of manufacturing flexibility and technological dimensions of manufacturing strategy on improving supply chain responsiveness: business environment perspective", International Journal of Production Research, Vol. 51 No. 18, pp. 5597-5611.

Körner, M., Lippenberger, C., Becker, S., Reichler, L., Müller, C., Zimmermann, L., Rundel, M. and Baumeister, H. (2016), "Knowledge integration, teamwork and performance in health care", Journal of Health, Organisation and Management, Vol. 30 No. 2, pp. 227-243.

Lau, H.C. and Lee, W.B. (2000), "On a responsive supply chain information system", International Journal of Physical Distribution and Logistics Management, Vol. 30 Nos 7-8, pp. 598-610.

Lorentz, H., Töyli, J., Solakivi, T. and Ojala, L. (2013), "Priorities and determinants for supply chain management skills development in manufacturing firms", Supply Chain Management: An International Journal, Vol. 18 No. 4, pp. 358-375.

Mandal, S. and Sarathy, R. (2018), "The effect of supply chain relationships on resilience: empirical evidence from India”, Global Business Review, Vol. 19 No. 3_suppl, pp. S196-S217.

McClelland, D.C. (1973), "Testing for competence rather than for intelligence", American Psychologist, Vol. 28 No. 1, p. 1.

Meethongjana, K. and Tachpetpaiboonb, N. (2015), "Competency-based training to develop basic computer skills for the elderly: a case study of the Dusit community, Bangkok, Thailand", Procedia-Social and Behavioral Sciences, Vol. 197, pp. 2520-2525.

Melnyk, S.A., Narasimhan, R. and DeCampos, H.A. (2014), "Supply chain design: issues, challenges, frameworks and solutions", International Journal of Production Research, Vol. 52 No. 7, pp. 1887-1896.

Mohammaddust, F., Rezapour, S., Farahani, R.Z., Mofidfar, M. and Hill, A. (2017), “Developing lean and responsive supply chains: a robust model for alternative risk mitigation strategies in supply chain designs", International Journal of Production Economics, Vol. 183, pp. $632-653$. 
Moyano-Fuentes, J., Sacristán-Díaz, M. and Garrido-Vega, P. (2016), "Improving supply chain responsiveness through Advanced Manufacturing Technology: the mediating role of internal and external integration", Production Planning and Control, Vol. 27 No. 9, pp. 686-697.

Parwez, S. (2016), "A conceptual model for integration of Indian food supply chains”, Global Business Review, Vol. 17 No. 4, pp. 834-850.

Pillania, R.K. (2006), "Leveraging knowledge for sustainable competitiveness in SMEs", International Journal of Globalisation and Small Business, Vol. 1 No. 4, pp. 393-406.

Prajogo, D. and Sohal, A. (2013), "Supply chain professionals: a study of competencies, use of technologies, and future challenges", International Journal of Operations and Production Management, Vol. 33 Nos 11-12, pp. 1532-1554.

Rubel, M.R.B., Rimi, N.N. and Walters, T. (2017), "Roles of emerging HRM and employee commitment: evidence from the banking industry of Bangladesh", Global Business Review, Vol. 18 No. 4, pp. 876-894.

Shou, Y. and Wang, W. (2017), "Multidimensional competences of supply chain managers: an empirical study", Enterprise Information Systems, Vol. 11 No. 1, pp. 58-74.

Sia, S.K. and Appu, A.V. (2015), "Work autonomy and workplace creativity: moderating role of task complexity", Global Business Review, Vol. 16 No. 5, pp. 772-784.

Simangunsong, E., Hendry, L.C. and Stevenson, M. (2016), "Managing supply chain uncertainty with emerging ethical issues", International Journal of Operations and Production Management, Vol. 36 No. 10, pp. 1272-1307.

Spencer, L.M., McClelland, D.C. and Spencer, S.M. (1993), Competency Assessment Methods: History and State of the Art, Hay-McBer Research Press, Boston.

Squire, B., Cousins, P.D., Lawson, B. and Brown, S. (2009), "The effect of supplier manufacturing capabilities on buyer responsiveness: the role of collaboration", International Journal of Operations and Production Management, Vol. 29 No. 8, pp. 766-788.

Suttiwatnaruput, K., Pornchaiviseskul, P. and Archiwaranguprok, S. (2014), "Supply chain manager competencies and their impact on supply chain integration", European Journal of Logistics purchasing and Supply Chain Management, Vol. 2 No. 1, pp. 71-90.

Sweeney, E. (2013), "Supply chain 'mega-trends': current status and future trends", Journal of the Chartered Institute of Logistics and Transport (CILT), Volume Spring, pp. 31-34.

Tabassi, A.A., Roufechaei, K.M., Ramli, M., Bakar, A.H.A., Ismail, R. and Pakir, A.H.K. (2016), "Leadership competences of sustainable construction project managers", Journal of Cleaner Production, Vol. 124, pp. 339-349.

Tatham, P., Wu, Y., Kovács, G. and Butcher, T. (2017), "Supply chain management skills to sense and seize opportunities", The International Journal of Logistics Management, Vol. 28 No. 2, pp. 266-289.

Thai, V.V., Cahoon, S. and Tran, H.T. (2011), "Skill requirements for logistics professionals: findings and implications", Asia Pacific Journal of Marketing and Logistics, Vol. 23 No. 4, pp. 553-574.

Viitala, R. (2005), "Perceived development needs of managers compared to an integrated management competency model", Journal of Workplace Learning, Vol. 17 No. 7, pp. 436-451.

Walters, D. and Rainbird, M. (2004), "The demand chain as an integral component of the value chain", Journal of Consumer Marketing, Vol. 21 No. 7, pp. 465-475.

Williams, B.D., Roh, J., Tokar, T. and Swink, M. (2013), "Leveraging supply chain visibility for responsiveness: the moderating role of internal integration", Journal of Operations Management, Vol. 31 Nos 7-8, pp. 543-554.

Wu, F., Yeniyurt, S., Kim, D. and Cavusgil, S.T. (2006), "The impact of information technology on supply chain capabilities and firm performance: a resource-based view", Industrial Marketing Management, Vol. 35 No. 4, pp. 493-504. 
EJMBE

30,2

210
Wu, Y.C., Kevin Huang, S., Goh, M. and Hsieh, Y.J. (2013), "Global logistics management curriculum: perspective from practitioners in Taiwan", Supply Chain Management: An International Journal, Vol. 18 No. 4, pp. 376-388.

\section{Corresponding author}

Yudi Fernando can be contacted at: yudi@ump.edu.my, yudi.fernando@binus.ac.id

For instructions on how to order reprints of this article, please visit our website: www.emeraldgrouppublishing.com/licensing/reprints.htm Or contact us for further details: permissions@emeraldinsight.com 